\title{
SANKSI HUKUM TERHADAP PELAKU TALAK DI LUAR PENGADILAN AGAMA
}

(Studi Perbandingan Pandangan Akademisi Hukum Positif dan Akademisi Hukum Islam di Kota Malang)

\author{
Muhammad Yalis Shokhib \\ Institut KH. Abdul Chalim Pacet Mojokerto \\ Email muhammad_yalis@yahoo.com
}

\begin{abstract}
Divorce out of court Religion is considered reasonable by some circles. But, actually that action is contrary to the Act No. 1 of 1974 article 39 that containing a moral message that divorce only be done in front of the Court of Session. Even in the article there is a clause of divorce mayhappen after the relevant Court attempted to reconcile the two sides. The researchers see the ambiguity based on need a new form of ijtihad gave rise to sanctions for perpetrators of Religious divorce out of court. The researcher using field research type because the research was did in the field. This research is descriptive, and the data sourceobtained from the results of interviews with academics positive law and academics Islamic law in Malang. The focus in this research are includes three ways, that are the position of the sanctions in the matter of divorce out of court Religion according to Islamic law, academics positive law view and Islamic academics law view in Malang, about divorce out of court sanction of religion. In this thesis, the researcher found the results of this research that is the sanctions law against divorce out of court Religion serves as reinforcement of laws and nas in the Qur'an, it is as a deterrent so that doesn't happen as much divorce politico hated God. The researchers choosethe legal sanction is the correct choice to given to perpetrators of Religious divorce out of court, legal sanctions in the form of a prohibition to perform a new marriage. In addition to fine sanctions that are capable of inflicting deterrent effect to offenders of religious divorce, out of court, so that someone will do a divorce before the trial Court religion, and also obedient to the Administration that have been arrange by the government.
\end{abstract}

Key Words: Sanction, Divorce, Positive Law, Islamic Law

\begin{abstract}
ABSTRAK
Talak di luar Pengadilan Agama merupakan hal yang dianggap wajar oleh beberapa kalangan. Padahal tindakan tersebut bertentangan dengan Undang-undang No. 1 tahun 1974 pasal 39 yang mengandung pesan moral bahwa perceraian hanya dapat dilakukan di depan sidang Pengadilan. Bahkan dalam pasal tersebut terdapat klausul perceraian dapat terjadi setelah Pengadilan yang bersangkutan berusaha mendamaikan kedua belah pihak. Jenis penelitian yang dipakai adalah penelitian lapangan (field research). Penelitian ini bersifat deskriptif, dan sumber data diperoleh dari hasil wawancara dengan akademisi hukum positif dan akademisi hukum Islam di kota Malang. Fokus dalam penelitian mencakup tiga hal, antara lain kedudukan sanksi dalam masalah talak di luar Pengadilan Agama menurut hukum Islam, pandangan akademisi hukum positif dan akademisi hukum Islam di Kota Malang tentang sanksi talak di luar Pengadilan Agama. Dalam artikel ini peneliti menemukan hasil bahwa pemberian sanksi hukum terhadap talak di luar Pengadilan Agama berkedudukan sebagai penguat Undang-undang dan nas dalam al-Qur'an, hal ini sebagai pencegah agar tidak terjadi banyaknya perceraian yang esensinya dibenci Allah. Peneliti memilih sanksi hukum adalah pilihan tepat untuk diberikan kepada pelaku talak di luar Pengadilan Agama, berupa sanksi hukum larangan untuk melakukan pernikahan baru.
\end{abstract}

Kata kunci: Sanksi, Talak, hukum positif, hukum Islam. 


\section{PENDAHULUAN}

Dalam ajaran Islam perkawinan memiliki landasan atau asas-asas yang dibentuk sebagai peringatan bagi setiap calon mempelai suami maupun istri yang akan melangsungkan perkawinan. Selain itu hukum perkawinan dalam agama Islam mempunyai kedudukan yang sangat penting, sehingga peraturan mengenai perkawinan diatur secara jelas dan rinci mulai dari urgensi perkawinan bagi manusia hingga asasasas yang harus dipahami setiap orang yang akan melangsungkan perkawinan. ${ }^{1}$

Asas-asas perkawinan adalah upaya Pemerintah untuk menyadarkan seseorang yang akan melangsungkan perkawinan, terutama pada huruf e disebutkan bahwa termasuk asas dalam perkawinan adalah mempersukar terjadinya perceraian, hal ini jelas bahwa aturan dalam Undang-undang adalah untuk memungkinkan setiap perceraian dilakukan di depan sidang Pengadilan. Artinya, meskipun perkawinan adalah sebuah ikatan suci atau mittsāqan galidza namun perbedaan atau pertentangan antara suami istri tidak dapat dipungkiri, karena meskipun perceraian adalah suatu tindakan yang tidak di inginkan setiap manusia, namun perceraian tetap tidak boleh dipandang mutlak sehingga ikatan perkawinan tidak dapat diputuskan. ${ }^{2}$

\footnotetext{
${ }^{1}$ Dalam Undang-undang perkawinan disebutkan Asas atau dasar seseorang melakukan perkawinan, antara lain :

a) Tujuan perkawinan adalah membentuk keluarga yang bahagia dan kekal sehingga antara keduanya diwajibkan saling membantu dan melengkapi agar masing-masing dapat mengembangkan kepribadian dan mencapai kesejahteraan spiritual dan material. b). Suatu perkawinan adalah sah apabila dilakukan menurut hukum masing-masing agamanya dan kepercayaannya. Setiap perkawinan harus dicatatkan menurut at uran Undang-undang yang berlaku. Pencatatan perkawinan sama halnya dengan masalah pencatatan peristiwa penting kehidupan seseorang seperti kelahiran, kematian, akte resmi yang dimuat dalam daftar pencatatan. c) Undang-undang perkawinan menganus asas monogamy. Untuk menikah lebih dari seorang hanya dapat dilakukan apabila dipenuhi beberapa persyaratan tertentu dan diputuskan oleh Pengadilan. d) Antara suami istri harus masak secara jiwa dan raganya untuk dapat melangsungkan perkawinan, hal ini bertujuan untuk mewujudkan tujuan perkawinan yang baik dan sehat (untuk menanggulangi laju kelahiran yang tinggi maka Pemerintah mengaskan larangan bagi calon suami istri yang masih dibawah umur). e) Tujuan utama dalam perkawinan adalah untuk membentuk keluarga yang bahagia, kekal dan sejahtera, maka Undang-undang perkawinan menganut asas mempersukar terjadinya perceraian untuk memungkinkan perceraian harus di depan sidang Pengadilan. f) Hak dan kedudukan suami istri adalah seimbang dengan kedudukan suami baik dalam kehidupan rumah tangga maupun dalam pergaulan masyarakat, sehingga dengan demikian segala masalah dalam keluarga dapat diseleseikan secara bersamasama.Lihat lebih lanjut Soemiyati, Hukum Perkawinan Islam Dan Undang-Undang Perkawinan 'UndangUndang No.1 Tahun 1974 Tentang Perkawinan', (Yogyakarta: Liberti, 2004), hlm. 3.

${ }^{2}$ Kamal Mukhtar, Asas-asas Hukum Perkawinan Islam Tentang Perkawinan, (Jakarta: Bulan Bintang, 1993), hlm. 4.
} 
Pernyataan di atas berdasarkan asumsi bahwa perkawinan tidak dapat dipandang sebagai sakramen atau ajaran suci. Dengan demikian perkawinan harus dipandang sebagai sesuatu yang alami, yang bisa bertahan atau putus di tengah perjalanan, apabila perkawinan dipertahankan akan mengakibatkan madzarat lebih besar, maka perceraian lebih baik dilaksanakan dengan catatan telah melaksanakan usaha damai yang maksimal. $^{3}$

Meksipun perceraian diperbolehkan dalam Islam, namun tindakan tersebut hanya diperbolehkan jika terjadi sesuatu yang mendesak atau emergency exit, artinya perceraian dilakukan bukan hanya berdasarkan ketidak cocokan, namun perceraian boleh dilakukan berdasarkan pertimbangan yang kuat, karena jika tidak dilaksanakan akan terjadi masalah yang lebih besar. ${ }^{4}$ Oleh sebab itu Allah membenci perceraian meskipun tindakan tersebut di halalkan.

Dalam sabda Nabi disebutkan: ${ }^{5}$

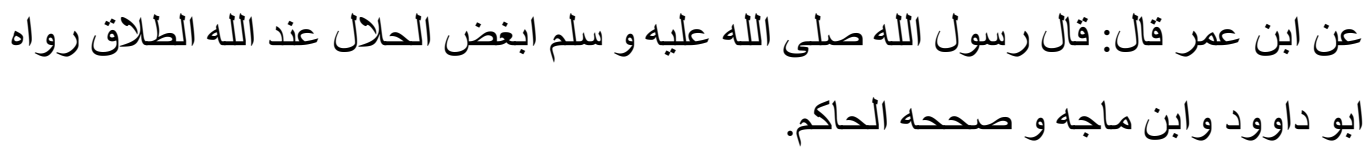

Artinya: "diriwayatkan dari Ibnu Umar, berkata: Rasulullah Saw. bersabda; perkara halal yang paling dibenci Allah adalah talak." (H.र. Abu Dawud dan Ibnu Majjah).

Hadis di atas merupakan bukti bahwa Allah membenci perceraian meskipun tindakan tersebut halal, dengan kata lain Allah lebih condong tidak menghendaki terjadinya perceraian. Kebencian Allah terhadap perceraian oleh Idris Ramulyo diterjemahkan sebagai tindakan yang kritis, karena perceraian mengakibatkan perpecahan antara dua orang yang berawal dari ikatan suci (pernikahan), karena menurutnya perbedaan antara dua orang merupakan bentuk kewajaran, sehingga segala resiko dalam perkawinan tergantung bagaimana suami istri menyikapinya. ${ }^{6}$

\footnotetext{
${ }^{3}$ Abdurahman Ghazali, Fiqih Munakahat, (Jakarta: Prenata Media, 2003), hlm. 1.

${ }^{4}$ Amiur Nuruddin dan Azhari Akmal Taringan,, Hukum Perdata Islam Di Indonesia "Studi Kritis Perkembangan hukum Islam UU 1/1974 Sampai KHI, (Jakarta: Kencana, 2006), hlm. 44.

${ }^{5}$ Abū Dāwud, Sunan Abū Dāwud, (Beirut: Dār al-Kutub al -'Ilmiyah, 2003), II:259.

${ }^{6}$ Muhammad Idris Ramulyo, Hukum Perkawinan Islam, (Jakarta: Balai Pustaka, 2003), hlm. 1.
} 
Perceraian dalam sebuah perkawinan tidak hanya mengakibatkan dampak psikologis, namun akibat perceraian juga berdampak terhadap masalah hak-hak pasangan suami istri. Mengenai akibat putusnya perkawinan, Khoiruddin Nasution menyebutkan bahwa akibat perceraian telah diatur dalam UU No.1 Tahun 1974 pasal $41^{7}$. Meskipun akibat terjadinya perceraian memberikan dampak dan tanggung jawab yang berat bagi pelakunya, masih banyak masyarakat yang memandang perceraian merupakan hal yang biasa. Ungkapan tersebut terbukti karena masih banyak masyarakat tanpa berfikir panjang mengucapkan talak tanpa memandang tempat ataupun waktu. Akibat emosi atau amarah seorang suami terkadang lalai mengucapkan talak terhadap istri, padahal dari ucapannya mengakibatkan perubahan hukum yang sangat signifikan yakni putusnya perkawinan. Dalam hadis Nabi disebutkan:

$$
\text { عن ابى هريرة قال : قال رسول الله صلى الله عليه و سلم ثلاث جد هن جد و ههزلهن جد: }
$$

Artinya: "Hadis diriwayatkan oleh abu Hurairah, Rasulullah bersabda tiga hal yang keseriusannya menjadi nyata dan bercandanya menjadi nyata, yaitu: Nikah, talak dan ruju'," (H.R. Imam empat)

Hadis di atas menjelaskan bahwa tiga perkara yang kesungguhannya mengakibatkan jatuhnya suatu hukum, dan bercandanya mengakibatkan jatuhnya hukum, yakni menikah, perceraian dan ruju'. ${ }^{8}$ Dari hadis ini seharusnya (des sollen) masyarakat berhati-hati dalam pengucapan talak terhadap istrinya, karena perkataan

\footnotetext{
${ }^{7}$ a) Ayah dan ibu tetap berkewajiban memelihara serta mendidik anaknya. b) Bapak bertanggung jawab at as seluruh kebutuhan anak hingga umur 21, kecuali jika tidak mampu, maka PA menetapkan ibu sebagai penanggungnya. c) Bekas suami wajib memberikan biaya kehidupan bagi bekas istri. d) Suami wajib memberikan mut'ah kepada bekas istri. e)Suami wajib memberi nafkah dan kiswah selama masa iddah dan harus melunasi mahar yang masih hutang. f) Bekas suami berhak merujuk bekas istri ketika masih dalam masa iddah, dan bekas istri wajib menjaga diri dengan tidak menerima pinangan orang lain ketika masih dalam masa iddah (KHI pasal 150). g) Hak asuh bagi anak yang belum mumayyiz diserahkan pada ibu, dan jika sudah mumayyiz hak asuh diserahkan pada anak untuk memilih, dan biaya pengasuhan ditanggung ayah, jika ayah atau ibu tidak mampu, maka hak asuh diserahkan pada kerabat atas kebijakan PA, dan dalam hal put usnya perkawinan tidak meyebabkan put usnya status hukum anak dan orang tuanya. h) Jika terjadi cerai mati, maka harta bersama menjadi pasangan yang masih hidup. Sedangkan akibat dari khulu' adalah perkawinan tidak dapat di rujuk kembali, begitu juga dengan $l i$ 'an, dan dalam li'an, anak yang yang dikandung dinasabkan pada ibunya, dan ayahnya tidak wajib menafkahi. Khoiruddin Nasution, Status Wanita di Asia Tenggara :Studi Terhadap Perundang-undangan Perkawinan Muslim Kontenporer Indonesia Dan Malaysia, (Jakarta : INIS, 2002), hlm. 379.

${ }^{8}$ Ibn Hajar al-'Atsqālani, Bulūgh al-Marām, (Surabaya: al-Hidayah, t.t), hlm. 24.
} 
tanpa unsur kesengajaan dapat jatuh dan mengakibatkan perubahan hukum yang sangat signifikan. Namun kenyataannya (des sein) masyarakat hanya memenangkan emosional tanpa memperhatikan perkataannya.

Jika diamati, aturan-aturan fikih berkenaan dengan talak, terkesan seoalah-olah fikih member aturan yang sangat longgar bahkan dalam tingkat tertentu memberikan kekuasaan yang terlalu besar pada laki-laki. Seolah-olah talak menjadi prerogratif lakilaki sehingga bisa saja seorang suami bertindak otoriter, misalnya menceraikan istri secara sepihak. ${ }^{9}$ Namun Islam membuat hukum tidak dimaksudkan agar mereka terlena dan lupa, tetapi justru dibuat untuk menyembuhkan dan memperbaiki berbagai kesalahan manusia serta menyelamatkan mereka dari kejahatan yang sangat membahayakan dan kerusakan yang lebih fatal.

Sedangkan dalam hukum positif kesannya memang mempersulit terjadinya perceraian antara suami dan istri dengan harapan agar dapat menekan tingginya angka perceraian. Salah satunya dengan adanya peraturan yang mengatur bahwa perceraian harus dilakukan di dalam persidangan Pengadilan. ketentuan-ketentuan tersebut tertuang dalam pasal-pasal berikut:

1) Undang-undang No. 1 tahun 1974, tentang perkawinan, "perceraian hanya dapat dilakukan di depan sidang Pengadilan setelah Pengadilan yang bersangkutan berusaha mendamaikan kedua belah pihak."10

2) Undang-undang No. 3 tahun 2006 tentang Peradilan Agama, "perceraian hanya dapat dilakukan di depan sidang Pengadilan setelah Pengadilan yang bersangkutan berusaha dan tidak berhasil mendamaikan kedua belah pihak."11

3) Kompilasi Hukum Islam, (KHI) "perceraian hanya dapat dilakukan di depan sidang Pengadilan Agama setelah Pengadilan Agama tersebut berusaha dan tidak berhasil mendamaikan kedua belah pihak"12

Walaupun perceraian merupakan urusan pribadi, baik atas kehendak bersama ataupun kehendak salah satu pihak yang seharusnya tidak perlu adanya campur tangan

\footnotetext{
${ }^{9}$ Ibid, Amiur Nuruddin dan Azhari Akmal Taringan, Hukum Perdata Islam di Indonesia, hlm. 214.

${ }^{10}$ Pasal 39 ayat 1 Undang-undang No. 1 tahun 1974.

${ }^{11}$ Pasal 65 Undang-undang No. 3 tahun 2006, pada pasal 65 Undang-undang No. 7 tahun 1989 mempunyai bunyi yang sama.

12 Pasal 115 Kompilasi Hukum Islam.
} 
dari Pemerintah, namun untuk menghindari tindakan sewenang-wenang terutama dari pihak suami dan juga demi kepastian hukum, maka perceraian harus melalui lembaga Pengadilan. walaupun dalam hukum Islam tidak ditentukan bahwa perceraian harus dilakukan di depan sidang Pengadilan seperti yang dikehendaki pada Undang-undang yang tersebut di atas, namun karena lebih banyak mendatangkan kebaikan bagi pihak suami dan istri, maka sudah sepantasnya umat Islam mengikuti ketentuan ini. ${ }^{13}$

Atas dasar akibat status hukum perkawinan suami yang mentalak istrinya meskipun tanpa kesengajaan, maka Pemerintah Indonesia perlu memperhatikan masalah sanksi hukum terhadap pelaku talak di luar Pengadilan Agama, karena talak di luar Pengadilan Agama akan mengakibatkan dampak buruk terutama bagi pihak istri. Pada prakteknya pengucapan talak di luar Pengadilan Agama sudah menjamur dimasyarakat akibat faktor emosional yang tidak dapat dikontrol, sehingga suami dengan mudah mengucapkan talak terhadap istri. Talak di luar Pengadilan Agama juga menimbulkan ketidak pastian hukum bagi istri sehingga istri kesulitan mengajukan gugatan apabila istri menerima kerugian, karena secara administratif perceraiannya tidak tercatatkan dan tidak melalui proses di Pengadilan Agama.

Melihat fenomena ini, peneliti merasa perlu melakukan penelitian secara mendalam untuk menggali hukum tentang sanksi terhadap talak di luar Pengadilan Agama. Peneliti akan menggali sumber dari akademisi hukum positif dan akademisi hukum Islam, karena akademisi hukum Islam yang akrab disebut dengan ulama adalah panutan utama umat dalam Islam setelah Nabi dan sahabatnya tiada, ${ }^{14}$ sehingga di era yang jauh dengan masa Nabi, ulama sebagai pewaris Nabi pantas menjadi penggantinya, terutama dalam hal penggalian hukum-hukum baru yang ketentuannya belum ditetapkan di era Nabi.

\section{TALAK DALAM HUKUM ISLAM}

Dalam al-Qur'an surah al-Baqarah disebutkan;

\footnotetext{
${ }^{13}$ Tarmizi M. Jakfar, Poligami dan Talak Liar dalam Perspektif Hakim Agama di Indoneisa, (Banda Aceh: ar-Raniry Press, 2007), hlm. 63.

${ }^{14}$ Juhaya S. Praja, Hukum Islam di Indonesia, hlm. 2.
} 
Artinya: "Talak itu dua kali, setelah itu suami diberi kelonggaran untuk rujuk (kembali) dengan baik, atau menceraikan dengan cara yang baik.” (Q.S. alBaqarah: 229).

Perceraian walaupun diperbolehkan tetapi agama Islam tetap memandang bahwa perceraian adalah sesuatu yang bertentangan dengan asas-asas hukum Islam.

Dalam sabda Nabi disebutkan: ${ }^{15}$

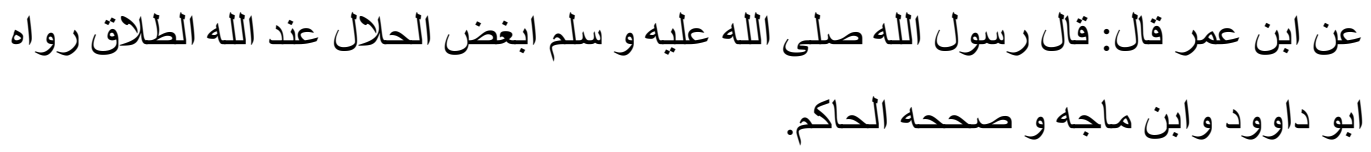

Artinya: "diriwayatkan dari Ibn Umar, berkata: Rasulullah Saw. bersabda; perkara halal yang paling dibenci Allah adalah talak."(H.R Abu Dawud dan Ibn Mājah).

Berdasarkan petunjuk hadis di atas, Islam mendorong terwujudnya perkawinan yang bahagia dan kekal serta menghindarkan terjadinya perceraian. Dapatlah dikatakan, pada prinsipnya Islam tidak memberi peluang untuk terjadinya perceraian kecuali pada hal-hal yang darurat. Talak itu walaupun diperbolehkan oleh agama, tetapi pelaksanaannya harus berdasarkan suatu alasan yang kuat dan merupakan jalan yang terakhir yang ditempuh oleh suami istri, apabila cara-cara lain yang telah diusahakan sebelumnya tetap tidak dapat mengembalikan keutuhan kehidupan rumahtangga suamiistri tersebut.

Menurut aturan Islam, perceraian diibaratkan seperti 'pembedahan yang menyakitkan' manusia yang sehat akalnya harus menahan sakit akibat lukanya. Dia bahkan siap di amputasi untuk menyelamatkan bagian tubuh lainnya sehingga tidak terkena luka atau infeksi yang lebih parah. Jika perselisihan antara suami dan istri tidak juga reda, dan jalan rujuk (berdamai kembali) tidak dapat ditempuh, maka perceraian adalah jalan "yang menyakitkan" yang harus dijalani. Itulah alasan mengapa jika tidak dapat rujuk lagi, maka perceraian di ambil. ${ }^{16}$

\section{TALAK DALAM HUKUM POSITIF}

\section{Perspektif Undang-undang Perkawinan}

\footnotetext{
${ }^{15}$ Abū Dāwud, Sunan Abū Dāwud, (Beirut: Dār al-Kutub al -'Ilmiyah, 2003), II:259.

${ }^{16}$ Yusuf Qaradhawi, Fiqih Wanita, (Bandung: Jabal, 2009), hlm. 56.
} 
Dalam Undang-undang Perkawinan telah disebutkan dalam pasal 1 UU No. 1 tahun 1974, dijelaskan bahwa tujuan perkawinan adalah membentuk keluarga yang bahagia, kekal berdasarkan Ketuhanan Yang Maha Esa, namun dalam realitanya sering perkawinan tersebut kandas di tengah jalan yang mengakibatkan putusnya perkawinan baik karena sebab kematian, perceraian ataupun karena putusan Pengadilan berdasarkan syarat-syarat yang telah ditetapkan oleh Undang-undang.

Ketentuan mengenai talak atau perceraian yang terdapat dalam Undang-undang Perkawinan No. 1 Tahun 1974 pasal 38 yaitu:

"Perkawinan dapat putus karena, a) kematian. b) perceraian dan c) atas keputusan Pengadilan."

Kematian sebagai salah satu sebab putusnya perkawinan adalah jika salah satu pihak baik suami atau istri meninggal dunia. Sedangkan untuk sebab perceraian, Undang-undang Perkawinan memberikan aturan-aturan yang telah baku, terperinci dan sangat jelas. Adapun putusnya perkawinan dengan keputusan Pengadilan adalah jika kepergian atau tidak hadirnya salah satu pihak dalam sidang Pengadilan. ${ }^{17}$

\section{Perspektif Kompilasi Hukum Islam (KHI)}

Kompilasi Hukum Islam juga mengikuti alur yang digunakan oleh Undangundang Perkawinan (UUP), walaupun pasal-pasal yang digunakan lebih banyak yang menunjukkan aturan-aturan yang lebih rinci. KHI memuat masalah put usnya perkawinan pada Bab XVI.

Pasal 113, dinyatakan:

"Perkawinan dapat putus, karena a) kematian, b) perceraian, dan c) atas put usan Pengadilan”.

Dalam perkawinan dapat putus disebabkan perceraian dijelaskan pada pasal 114 yang membagi perceraian kepada dua bagian, perceraian yang disebabkan karena talak dan perceraian yang disebabkan oleh gugatan perceraian.

Berbeda dengan Undang-undang Perkawinan yang tidak mengenal istilah talak, Kompilasi Hukum Islam yang dimaksud dengan talak adalah, ikrar suami dihadapan

\footnotetext{
${ }^{17}$ Ibid, Amiur Nuruddin dan Azhari Akmal Tarigan, Hukum Perdata Islam, hlm. 216.
} 
sidang Pengadilan Agama yang menjadi salah satu sebab putusnya perkawinan. Di dalam KHI mensyaratkan bahwa ikrar suami untuk bercerai (talak) harus disampaikan di hadapan sidang Pengadilan Agama. ${ }^{18}$

Selanjutnya perceraian hanya dapat dilakukan di depan sidang Pengadilan sebagaimana yang termuat dalam perundang-undangan di bawah ini.

Pasal 39 Undang-undang Perkawinan No. 1 Tahun 1974 :

1) Perceraian hanya dapat dilakukan di depan sidang Pengadilan setelah Pengadilan yang bersangkutan berusaha dan tidak berhasil mendamaikan kedua belah pihak.

2) Untuk melakukan perceraian, harus ada cukup alasan, bahwa antara suami istri itu tidak akan dapat hidup rukun sebagai suami istri. ${ }^{19}$

3) Tata cara perceraian di depan sidang Pengadilan diatur dalam peraturan perundangan sendiri.

Pasal 65 Undang-undang No. 7 Tahun 1989 tentang Peradilan Agama, dijelaskan: "Perceraian hanya dapat di lakukan di depan sidang Pengadilan setelah Pengadilan yang bersangkutan berusaha dan tidak berhasil mendamaikan kedua belah pihak".

Pasal 115, Kompilasi Hukum Islam, dinyatakan;

"Perceraian hanya di lakukan di depan sidang Pengadilan Agama setelah Pengadilan Agama tersebut berusaha dan tidak berhasil mendamaikan kedua belah pihak. Berkenaan dengan tempat di mana perceraian dilakukan sepertinya tidak ada perbedaan antara Undang-undang Perkawinan No. 1 Tahun 1974, Undang-undang Peradilan Agama dan Kompilasi Hukum Islam”.

\footnotetext{
${ }^{18}$ Ibid, Amiur Nuruddin dan Azhari Akmal Tarigan, Hukum Perdata Islam,.. hlm. 220.

${ }^{19}$ Undang-undang No. 1 tahun 1974, pasal 39 ayat (1) dan (2). Dalam penjelasan UU tersebut ditetapkan bahwa alasan-alasan yang dapat dijadikan dasar perceraian adalah: a). salah satu pihak berbuat zina atau menjadi pemabuk, pemadat, dan penjudi yang sulit disembuhkan; b) salah satu pihak meninggalkan yang lain selama dua tahun berturut-turut tanpa izin pihak yang lain dan tanpa alasan yang sah atau karena hal lain di luar kemampuannya; c) salah satu pihak mendapatkan hukuman penjara selama lima tahun atau hukuman yang lebih berat setelah perkawinan berlangsung; d) salah satu pihak melakukan kekejaman atau penganiyaan berat yang membahayakan pihak lain; e) salah satu pihak cacat badan atau penyakit, yang membuat bersangkutan tidak dapat menjalankan kewajiban sebagai suami atau istri; dan f) antara suami istri terus-menerus terjadi perselisiahan dan pertengkaran sehingga tidak ada harapan akan hidup rukun lagi dalam rumah tangga. Lihat penjelasan atas Undang-undang No. 1 tahun 1974 tentang perkawinan, pasal 39 ayat (2).
} 


\section{Perspektif Burgerlijk Wetboek(B.W)}

Dalam hukum perundang-undangan sipil atau Burgerlijk Wetboek (B.W) pasal 209 disebutkan, Perceraian adalah pengakhiran suatu pernikahan karena suatu sebab dengan keputusan hakim. Perceraian atas persetujuan suami atau istri yang tidak diperkenankan harus ada alasan-alasan yang sah.

Alasan-alasan ini ada empat macam antara lain; ${ }^{20}$

a. Zina (Overspel).

b. Ditinggalkan dengan sengaja (kwaadwillige verlating).

c. Penghukuman yang melebihi lima tahun karena dipersalahkan melakkukan suatu kejahatan.

d. Penganiyaan berat atau membahayakn jiwa.

\section{SEBAB DAN MEKANISME PUTUSNYA PERKAWINA}

Sebab putusnya perkawinan diawali oleh beberapa hal seperti talak, gugat cerai, fasakh, khulū', syiqāq, ta'liq talāq dan li'ān. ${ }^{21}$ Adapun proses perceraian dengan talak diawali dengan mengajukan surat pemberitahuan maksud menceraikan istri ke Pengadilan Agama untuk disidangkan, kemudian pemeriksaan secara tertutup yang meliputi pemanggilan para pihak untuk dimintai penjelasan tentang maksud perceraian, disertai dengan usaha mendamaikan oleh hakim, kepada kedua belah pihak hingga proses pengucapan ikrar talak. ${ }^{22}$

\footnotetext{
${ }^{20}$ Saifullah, Buku Ajar Konsep dasar Hukum Perdata Bagian 1, (Malang: Fakultas Syar'ah UIN Malang, 2004), hlm. 28.

${ }^{21}$ Talak adalah putusnya ikatan perkawinan yang di ajukan pihak suami, sedangkan gugat cerai adalah put usnya perkawinan yang diajukan oleh pihak istri, dalam hal ini istilah gugat cerai menjadi istilah cerai gugat bersamaan dengan perubahan UU Pengadilan Agama No. 7 Tahun 1989 menuju UU No. 4 Tahun 2004. Lihat lebih lanjut Yahya harahap, Hukum Perkawinan Nasional (Medan: Zahir trading, 1975), hlm. 35. Fasakh adalah rusaknya suatu ikatan perkawinan atas permintaan salah satu pihak atau oleh hakim pengadilan agama, hal ini dapat terjadi akibat penipuan atau ditemukan sebuah cela pada salah satu pihak. Khulu' adalah bentuk perceraian at as persetujuan suami dan istri dengan jatuhnya talak satu dari suami kepada istri dengan tebusan harta atau uang dari pihak istri yang menginginkan perceraian. Sedangkan syiqaq adalah perselisihan antara suami dan istri yang diseleseikan oleh seorang hạkam. Ta'liq talaq adalah suatu talak yang digantungkan pada suatu hal yang mungkin terjadi dan telah disebutkan dalam sebuah perjanjian yang telha disepakati dan dioerjanjikan terlebih dahulu, dan $l i$ 'an adalah sumpah suami kepada istri yang menuduh istrinya berzina, yang di dalamnya terdapat pernyataan bersedia menerima laknat dari Allah apabila yang mengucapkan sumpah tersebut berdusta. Lihat lebih lanjut Ahmad Aulawi, Hukum Perkawinan Di Indonesia, (Jakarta: Bulan bintang, 2004), hlm. 52-53.
}

${ }^{22}$ Jika pihak Pengadilan tidak berhasil mendamaikan, maka dilanjutkan dengan putusan (penetapan dikabulkannya permohonan), kemudian Pengadilan Agama memberitahukan ikrar talak bukan 
Sebab putusnya perkawinan yang kedua adalah gugat cerai, dalam gugat cerai pengajuan permohonan perceraian muncul dari pihak istri, kemudian istri atau kuasa hukum mengajukan gugatan cerai kepada Pengadilan Agama, selanjutnya sebagaimana proses dalam talak, hanya saja talak jatuh karena ikrar talak suami, sedangkan gugat cerai di jatuhkan oleh Pengadilan.

Penyebab putusnya perkawinan yang ketiga adalah fasakh atau rusaknya hubungan perkawinan, dalam hal ini terdapat tiga hal penyebab batalnya perkawinan antara lain: batal sendiri karena tidak tahu, dapat dibatalkan dan diperbarui, batal perkawinan dalam jangka waktu tertentu. ${ }^{23}$ Berkaitan dengan putusnya perkawinan sebab kematian, perceraian, maupun karena putusan Pengadilan, Undang-undang No.1 Tahun 1974 pasal 38 dan KHI pasal 13 menyebutkan bahwa terjadinya perceraian hanya dapat dilakukan di depan sidang Pengadilan Agama, dan hanya dapat di buktikan dengan surat cerai. $^{24}$

Penyebab putusnya perkawinan terjadi pula akibat Khulu' (perceraian yang terjadi atas permohonan istri dengan memberikan tebusan atau 'iwädh kepada suami sekaligus atas persetujuannya. Adapun proses khulü, diawali istri mengajukan permohonan serta pemerikasaan yang meliputi pemanggilan oleh Pihak Pengadilan Agama untuk dimintai keterangan dan diberi penjelasan tentang akibat khulü, dengan disertai nasihat-nasihat, selanjutnya put usan Pengadilan Agama berupa izin ikrar talak suami apabila kedua belah pihak telah sepakat tentang besarnya jumlah ' $i w a \bar{d} h$,

pengabsahan talak, yang hanya dapat dilakukan di depan Sidang Pengadilan Agama (KHI pasal 115), setelah ikrar talak perceraian terhitung antara suami istri, kemudian pemohon diperbolehkan mengajukan hak penguasaan anak, nafkah anak dan istri, pembagian harta, atau permohonan tersebut boleh dimohon bersamaan dengan permohonan cerai, namun sebelum adanya penetapan dari Pengadilan Agama tentang dikabulkannya permohonan talak, istri dapat mengajukan banding atau kasasi. (UU No. 7 tahun 1975) dan sebagai cat at an bahwa perundang-undangan Indonesia tidak mengenal talak tiga. Syahar Saidus, Undangundang Dan Masalah Pelaksanaanya (Ditinjau Dari Segi Hukum Islam), (Bandung : Penerbit Alumni, 1981), hlm. 36.

${ }^{23}$ Adakalanya dalam masalah fasakh sebab terjadinya pembatalan perkawinan adalah karena melanggar larangan perkawinan, yang telah disebutkan dalam KHI pasal 39-44, dan ada yang beranggapan bahwa pembatalan perkawinan adalah disebabkan karena melanggar UU No. 1 Tahun 1974 pasal 26, dan KHI pasal 71.

${ }^{24}$ Adapun proses fasakh adalah sebagaimana proses dalam cerai gugat yang dijatuhkan oleh Pengadilan, kemudian jatuh putusan setelah berkekuatan hukum tetap. Syahar Saidus, Undang-undang Dan Masalah Pelaksanaanya, hlm.36. 
kemudian Pengadilan membuat penetapan tentang terjadinya talak dengan penegasan bahwa khulü' berdasarkan alasan perceraian. ${ }^{25}$

Adapun syiqāq (perselisihan antara suami istri secara terus menerus dan tidak ada harapan untuk rukun kembali dalam rumah tangga), sebagaimana proses perceraian yang lain proses syiqāq dimulai dari pengajuan perkara ke Pengadilan Agama tempat kediaman tergugat, dilengkapi dengan keterangan-keterangan saksi dan keluarga terdekat dan berakhir dengan putusan. Sebelum memutus gugatan, pihak Pengadilan Agama mengangkat hakam dari keluarga dekat atau orang lain. ${ }^{26}$

Sedangkan pelanggaran perjanjian (ta'liq talāq) sebagaimana penyebab perceraian yang lainnya juga harus mengikuti proses, sehingga pelanggaran perjanjian tidak dengan sendirinya jatuh talak, namun tetap diproses dari pengajuan perkara oleh istri kepada pihak Pengadilan Agama, kemudian pemeriksaan dan putusan. ${ }^{27}$ Penyebab putusnya perkawinan yang terakhir adalah li 'ān (suami menuduh istri berzina, atau mengingkari anak dalam kandungan atau sudah lahir, dan istri menolak tuduhan tersebut). Dalam hal ini proses perceraian hanya dapat dilakukan di depan Pengadilan Agama. Dalam hal ini selamanya suami istri tidak dapat bersama lagi. ${ }^{28}$

Dalam proses perceraian berdasarkan pasal 215 Jo 486 Burgerlijk Wetboek(B.W) tuntutan perceraian harus diajukan di Pengadilan Negeri tempat tinggal (utama) suami, kecuali suami tidak bertempat tinggal di Indonesia atau tidak diketahui tempat tinggalnya, dalam hal ini permohonan dapat di lakukan pada Pengadilan Negeri di tempat tinggal istri. ${ }^{29}$

\footnotetext{
${ }^{25}$ Mengenai khulü'Muhammad Bin Qasim al-Ghazi menyebutkan bahwa khulu' adalah perceraian dengan tebusan yang disengaja. Khulü' diperbolehkan atas tebusan dan dikuas akan penyerahanya. Khulu' harus disertai dengan tebusan yang diketahui jumlahnya, Jika tidak maka hal tersebut menjadi talāq bä'in dengan mahar misil, seperti halnya seorang suami mengkhulu' istrinya atas selembar pakaian yang ditentukan, maka yang demikian jatuh sebagai talak ba'in bukan khulu', karena khulü' jatuh atas permohonan istri dan dengan jumlah tebusan yang jelas. Muhammad Bin Qasim, Fathul Qarib Terjemah Ahmad Sunarto, (Surabaya: al-Hidayah, 1992) II: 61-62.

${ }^{26}$ Syahar Saidus, Undang-undang Dan Masalah Pelaksanaanya, hlm.36.

${ }^{27}$ Adapun hukuman bagi seseorang yang melanggar tata cara perceraian, maka baginya terkena denda maksimal Rp50, dan bagi Pegawai Negeri Sipil terkena sanksi penurunan pangkat dengan pemberhentian dengan tidak hormat. Dari seluruh proses perceraian yang telah disebutkan di atas, secara garis besar menunjukan bahwa perceraian harus dengan alasan yang kongkrit, jalan terbaik dari proses talak adalah melalui pengadilan. Syahar Saidus, Undang-undang Dan Masalah Pelaksanaanya, hlm.36..

${ }^{28}$ Dalam hukum Islam bagi pelaku sumpah $l i$ 'ann mendapatkan hukuman jilid sebanyak delapan puluh kali, kecuali jika suami mampu mendatangkan empat saksi. Lihat lebih lanjut dalam Muhammad Bin Qasim, Fathul Qarib Terjemah Ahmad Sunarto, hlm. 82.

${ }^{29}$ Saifullah, Buku Ajar Konsep dasar Hukum Perdata, hlm. 28-29.
} 


\section{EKSPLORASI UNDANG-UNDANG MENGENAI PERCERAIAN DAN SANKSI DI NEGARA MUSLIM}

Pemberlakuan sanksi hukum menjadi salah satu ciri dalam Undang-undang hukum keluarga di Negara-negara Muslim modern. Secara umum sanksi hukum terkait dengan pelanggaran berbagai masalah seputar perkawinan, perceraian, nafkah, perlakuan terhadap istri, hak perempuan pasca cerai, dan hak waris. Dalam hal ini penulis akan memaparkan Undang-undang mengenai perceraian berikut sanksinya di Negara Muslim.

Untuk memperoleh gambaran yang lebih jelas, berikut rincian sejumlah persoalan tersebut:

Di Malaysia alasan perceraian sama dengan alasan terjadinya fasākh atau batalnya perkawinan, dalam hal ini terdapat beberapa pembagian: ${ }^{30}$

a) Undang-undang perak dan Pahang menyebutkan lima alasan perceraian, antara lain : suami impoten, gila, mengidap penyakit kusta atau penyakit kelamin, sehingga istri tidak rela, izin perkawinan dari istri tidak sah, baik karena paksaan, hilang akal atau karena lalai, suami sakit saraf saat melangsungkan perkawinan, atau alasan lain yang pantas untuk fasakh menurut syari'ah.

b) Kelantan menyebutkan enam alasan perceraian, yang isinya sama dengan Undang-undang perak dan Pahang, hanya saja ditambahkan istri di kawinkan sebelum dewasa, dan setelah umur 18 tahun istri menolak perkawinan tersebut, dan pada waktu menikah istri sakit jiwa.

c) Undang-undang Serawak menyebutkan 13 alasan perceraian, sama dengan Kelantan, hanya saja ditambahkan istri memiliki cacat badan sehingga menghalangi bersetubuh dengan suaminya.

Meskipun seluruh Undang-undang menjadikan gila sebagai alasan perceraian, namun Undang-undang Negeri Sembilan, pulau pinang, Selangor dan serawak menyebutkan gila terbatas minimal dua tahun. sedangkan Kelantan, Pahang dan Perak

\footnotetext{
${ }^{30}$ Khoirudin Nasution, Hukum Keluarga di Dunia Islam Modern, Studi Perbandingan Dan Keberanjakan UU Modern Dari Kitab-Kitab Fikih, (Jakarta: Ciputat Press, 2003), hlm. 233.
} 
tidak menyebutkan batas minimal. Pada dasarnya diperbolehkan memasukkan segala alasan global untuk melangsungkan perceraian, asalkan sesuai ketentuan syari'ah. ${ }^{31}$

Mengenai proses perceraian, secara umum Negara-negara Muslim di Asia melalui beberapa langkah, antara lain: ${ }^{32}$

1) Pengajuan permohonan ke Pengadilan dengan beserta alasan-alasan konkrit.

2) Pemerikasaan perkara yang meliputi pemanggilan oleh pihak Pengadilan.

3) Usaha perdamaian oleh Pengadilan, dan

4) Putusan.

Dalam proses pendamaian, terdapat perbedaan antara pemohon yang disepakati keduanya dan pemohon sepihak. Bagi pemohon yang disepakati dua belah pihak ketika keduanya sudah tidak dapat didamaikan dalam masa waktu enam bulan atau lebih dengan persetujuan dari Pengadilan, maka suami di persilahkan untuk mengucapkan ikrar talak di depan Pengadilan. Namun untuk pemohon sepihak jika masih mungkin didamaikan maka Pengadilan mengutus jurủ damai dari Pengadilan, atau mendatangkan pembela atau pengacara. ${ }^{33}$

Untuk perceraian dengan alasan tebus talak atau khulü'proses perceraian dimulai dari menunggu jika keduanya sudah menyetujui akan biaya pembayaran, kemudian Pengadilan menyuruh suami untuk melakukan ikrar talak, jika suami enggan namun pihak Pengadilan memandang bercerai lebih baik, maka Pengadilan boleh menjatuhkan talak dengan katagori talak bä'in sughrā. Sedangkan untuk proses perceraian dengan ta' $\bar{i} q$ talāq, istri melapor tentang adanya pelanggaran dalam ta' $\bar{i} q$ talāq, jika terbukti benar maka diadakan sidang perceraian yang kemudian direkam untuk dicatatkan. Untuk

\footnotetext{
${ }^{31}$ Untuk perkawinan paksa, Undang-undang Negeri Sembilan, pulau pinang, Selangor dan serawak, mencatat sebagai alasan perkawinan, karena mencat at harus ada persetujuan bagi calon mempelai ketika hendak menikah, namun tidak demikian bagi Kelantan, karena bagi Kelantan, secara tekstual tidak harus ada persetujuan bagi calon mempelai ketika hendak menikah. Secara umum Undang-undang di Malaysia menyebutkan 4 hal sebagai penyebab perceraian, yakni karena talak at au perintah talak, tebus talak, ta'kliq talāq dan syiqā $q$, hanya Undang-undang Serawak yang menyebutkan $l i$ ' $a ̄ n$ sebagai alasan perceraian. Ibid., hlm. 234-235.

${ }^{32}$ Ibid., hlm. 236-237.

33 Ibid., hlm. 239.
} 
proses perceraian karena syiqāq, sama dengan proses talak dan tebus talak, sedangkan li' ${ }^{\prime} \bar{n}$ hanya disebutkan agar Pengadilan merekam perceraian akibat sumpah $l i{ }^{\prime} \bar{a}{ }^{34}$

Di Tunisia sebagaimana Negara muslim yang lain, perceraian bisa jatuh hanya di depan Pengadilan setelah ada usaha damai, suami tidak boleh kawin lagi dengan istri yang telah di talak tiga, dan istri boleh meminta cerai tanpa alasan hukum dengan syarat membayar kompensasi sesuai keputusan hakim. Di Maroko istri diperbolehkan membuat ta'Tiq talāq yang berisi poligami bisa menjadi alasan perceraian, dan perceraian didaftarkan oleh dua orang, artinya di Maroko diperbolehkan perceraian di luar Pengadilan. Sedangkan di Irak suami yang menceraikan istri dianjurkan di hadapan Pengadilan, namun wajib bagi suami untuk mendaftarkan ke Pengadilan selama masa istri dalam iddah. Di Somalia talak harus di hadapan Pengadilan setelah dinyatakan usaha perdamaian tidak berhasil, begitu juga di al-Jazair, hanya saja perceraian dihitung setelah direkam oleh Pengadilan. ${ }^{35}$

\section{SANKSI TALAK DI HADAPAN PENGADILAN DAN PENDAFTARAN PERCERAIAN}

Dalam masalah sanksi talak di luar Pengadilan, Negara Iran, Malaysia, Mesir, Pakistan, Yordania, dan Srilanka mencantumkan sanksi hukum dalam pasal-pasal hukum keluarga mereka terkait persoalan ini, antara lain:

a. Di Iran, perceraian hanya bisa berlaku di depan Pengadilan dengan sertifikat yang menyatakan pasangan tidak mungkin hidup bersama, baik perceraian yang

\footnotetext{
${ }^{34}$ Secara umum proses perceraian dalam perundang-undangan Malaysia terdiri atas beberapa hal, selain perceraian harus di laksanakan di depan Pengadilan, perceraian harus diaftarkan, karena perceraian yang diakui hanya yang didaftarkan, dan seorang janda boleh melangsungkan perkawinan lagi jika sudah punya surat cerai, pengakuan cerai dari hakim, dan surat keterangan kematian bagi istri yang tertalak karena kematian suami. Dan bagi suami istri yang tidak mengikuti proses perceraian sebagaimana ketentuan dalam UU akan mendapatkan denda 1000 ringgit atau keduanya di penjara selama enam bulan. Ibid., hlm. 240.

${ }^{35}$ Poligami bisa menjadi alasan perceraian dan istri berhak mendapat kompensasi jika suami menceraiakan tanpa alasan, dan di Libiya, perceraian hanya bisa dilaksanakan di depan Pengadilan dan alasan tidak sekufu bisa menjadi alasan perceraian. Ibid., hlm. 251-253.
} 
diajukan satu pihak ${ }^{36}$ maupun yang disetujui bersama. ${ }^{37}$ Pernyataan tersebut harus didahului usaha pendamaian, serta dibatasi jangka waktu tiga bulan. Sehingga bagi suami yang melakukan perceraian atau menarik kembali penjatuhan talak atau cerai yang dilakukan tanpa registrasi dapat diancam hukuman penjara satu hingga enam bulan.

b. Menurut ketentuan hukum keluarga di Malaysia, penjatuhan talak di luar dan tanpa izin Pengadilan dapat dikenakan denda 1000 ringgit atau penjara maksimal enam bulan atau keduanya-duanya. ${ }^{38}$

c. Dalam Undang-undang Mesir No. 25 Tahun $1920^{39}$ mencatat hak talak yang isinya hak Pengadilan untuk menjatuhkan talak dengan alasan suami tidak mampu memberikan nafkah, dan talak jatuh karena ada penyakit yang membahayakan, suami berkelakuan tidak baik atau meninggalkan istri terlalu lama. Di Negara Mesir poligami bisa menjadi alasan perceraian, dan perceraian dapat dilakukan secara sepihak. Begitu juga dengan ketentuan bercerai hanya dapat dijalankan di depan Pengadilan beserta izin hakim. Namun pada Tahun 1985 sudah ditetapkan bahwa perceraian harus dicatatkan dalam sebuah sertifikat.

Berdasarkan Law on Personal Status 1929 yang dipertegas lagi dalam amandemennya Undang-undang No.100 1985 Pasal 23 A, suami yang tidak melakukan pendaftaran perceraian dapat dijatuhi hukuman penjara hingga enam bulan; atau denda 200 pound; atau keduanya sekaligus. Begitu pula petugas pencatatan yang menolak atau tidak melaksanakan tugas pencatatan perceraian dapat dikenakan sanksi penjara maksimal 1 bulan dan denda minimal 50 pound Mesir.

\footnotetext{
${ }^{36}$ The Family Protection Law, tahun 1967 pasal 8, "Perceraian dapat terjadi setelah mendapat sertifikat dari Pengadilan yang menyatakan kedua belah pihak tidak mungkin hidup rukun lagi”. Ibid., hlm. 248.

${ }^{37}$ The Family Protection Law, tahun 1967 pasal 9, "Perceraian dapat terjadi dengan kesepakatan berdua suami dan istri. Untuk kasus ini suami dan istri harus lebih dahulu mendapat sertifikat dari Pengadilan yang menyatakan mereka berdua tidak mungkin berdamai".ibid., hlm. 248.

${ }^{38}$ UU Persekutuan pasal 124, Ibid., hlm. 244.

${ }^{39}$ Ibid., hlm. 245-246.
} 
d. Pakistan, India dan Bangladesh, masih mengakui perceraian di luar Pengadilan. ${ }^{40}$ Berdasarkan The Dissolution Of Muslim Marriage act 1939, kemudian diperbarui tahun 1961, suami yang ingin berpoligami bisa menjadi alasan perceraian, dan istri yang dimadu oleh suami boleh mengajukan perceraian. Bagi suami yang menceraikan istri tanpa mengajukan permohonan tertulis kepada Pejabat (chairman) yang berwenang, atau tanpa memberikan salinan (copy) nya kepada istri dapat dihukum penjara maksimal satu tahun, atau denda maksimal 5.000 rupee, dan atau keduanya sekaligus.

e. Yordania memberlakukan hukuman menurut Undang-undang Hukum Pidana Negara itu terhadap suami yang menceraikan istri (di luar Pengadilan) tanpa melakukan langkah registrasi. Bagi yang tidak melaporkan dapat dihukum dengan Hukuman Pidana Yordania maksimal 1 bulan atau denda maksimal 15 dinar. $^{41}$

f. Brunai Darussalam ${ }^{42}$ masih mengakui adanya cerai di luar Pengadilan, meskipun setelah terjadi perceraian (talak) harus didaftarkan di Pengadilan. Negara Filipina mengharuskan pendaftaran perceraian secara administratif. ${ }^{43}$

g. Negara Lebanon mengakui keabsahan talak di luar Pengadilan, dengan syarat ada pemberitahuan setelah melakukannya. Namun pihak istri berhak membuat ta' $\sqrt{i} q$ talāq ketika akad nikah. Dalam Undang-undang Druze Lebanon No. 24 tahun 1948, perceraian hanya dapat berlaku atas put usan hakim di Pengadilan, ${ }^{44}$ dengan disertai dua saksi, dan istri yang telah diceraikan tidak boleh dinikahi kembali.

\footnotetext{
${ }^{40}$ The Muslim Family Laws Ordinance, tahun 1961 pasal 7 (1), "seorang suami yang menceraikan istrinya, segera setelah ikrar talak harus membuat laporan tertulis kepada ketua Arbitration Council, dan satu kopi dikirim ke sitrinya".Ibid., hlm. 249.

${ }^{41}$ Dalam UU Yordania No. 61 Tahun 1976 pasal 101, disebutkan, "seorang suami wajib mendaftarkan talak yang dilakukannya setelah ada keputusan hakim, dan jika talak dilakukan di luar Pengadilan dan belum didaftarkan, suami wajib mendaftarkan ke Pengadilan dalam jangka waktu 13 hari setelah melakukan talak”. Ibid., hlm. 249.

${ }^{42}$ Religius Council and Kadis Court Chap. 77 pasal 144 ayat (1), "seseorang suami boleh menceraikan istrinya sesuai dengan hukum Islam". ayat (2), "Dalam waktu tujuh hari setelah menceraikan, suami seyogyanya melaporkan kepada pendaftar yang berwenang" Ibid., hlm 245.

${ }^{43}$ Code Of Muslim Personal Laws Of The Philippines, tahun 1977 pasal 81, "sekretaris Pengadilan, harus mencatatkan perkawinan Muslim, perceraian dan pertukaran agama". Ibid., hlm. 245.

${ }^{44}$ Undang-undang Druze Lebanon No. 24 tahun 1948 pasal 42, "pasangan boleh bercerai dengan kesepakatan bersama, yang dilakukan dengan lebih dahulu mengumumkan dan ikrar talak yang dihadiri dua orang saksi setelah ada keputusan hakim". Ibid., hlm. 247.
} 
Jika percekcokan timbul dari suami, maka suami harus membayar sisa mahar yang belum dibayar, begitu juga dengan istri, jika sumber masalah timbul dari istri, maka istri harus mengikhlaskan sisa mahar yang belum dibayar.

Tabel 1.2 Jenis-jenis sanksi di Negara Muslim

\begin{tabular}{|c|l|l|l|}
\hline No & \multicolumn{1}{|c|}{ Negara } & \multicolumn{1}{|c|}{ Jenis Sanksi } & \multicolumn{1}{|c|}{ Keterangan } \\
\hline 1 & Iran & $\begin{array}{l}\text { Penjara satu bulan } \\
\text { hingga enam bulan. }\end{array}$ & $\begin{array}{l}\text { Perceraian yang dilakukan tanpa } \\
\text { registrasi. }\end{array}$ \\
\hline 2 & Malaysia & $\begin{array}{l}\text { Denda 1000 ringgit } \\
\text { atau penjara maksimal } \\
\text { enam bulan. }\end{array}$ & $\begin{array}{l}\text { Penjatuhan talak di luar tanpa } \\
\text { izin Pengadilan. }\end{array}$ \\
\hline 3 & Mesir & $\begin{array}{l}\text { Penjara enam bulan } \\
\text { atau denda 200 pound, } \\
\text { atau keduanya } \\
\text { sekaligus. }\end{array}$ & $\begin{array}{l}\text { Suami yang tidak melakukan } \\
\text { pendaftaran perceraian. }\end{array}$ \\
\hline 4 & Pakistan & $\begin{array}{l}\text { Penjara maksimal satu } \\
\text { tahun atau denda } \\
\text { maksimal 5.000 rupee, } \\
\text { dan atau keduanya. }\end{array}$ & $\begin{array}{l}\text { Menceraiakn istri tanpa } \\
\text { mengajukan permohonan tertulis } \\
\text { kepada pejabat yang berwenang. }\end{array}$ \\
\hline 5 & Yordania & $\begin{array}{l}\text { Penjara maksimal satu } \\
\text { bulan atau denda } \\
\text { maksimal 15 dinar. }\end{array}$ & $\begin{array}{l}\text { Menceraikan istri di luar } \\
\text { Pengadilan tanpa melakukan } \\
\text { langkah registrasi. }\end{array}$ \\
\hline
\end{tabular}

Dari keterangan di atas dapat diketahui beberapa hal mengenai sanksi di beberapa Negara Muslim:

a. Negara-negara Islam telah mencapai skala mayoritas dalam memberlakukan peraturan di Negaranya agar setiap warga negaranya melakukan perceraian melalui prosedur dihadapan pengadilan. Perceraian harus di daftarkan dengan dihadiri dua orang saksi setelah pengadilan berusaha mendamaikan dua belah pihak, karena keharusan di Pengadilan di dasarkan pada ketetapan harus melibatkan hakam dalam percekcokan keluarga.

b. Meskipun secara umum sanksi yang dijatuhkan masih diarahkan kepada pelaku pelanggaran, namun di beberapa Negara, selain pelaku hukuman juga dijatuhkan 
kepada pihak pendukung, penyelenggara bahkan petugas berwenang yang terkait dengan pelanggaran.

c. Sanksi yang diberikan pada umumnya berupa hukuman penjara atau denda, bahkan keduanya sekaligus. Meskipun bersifat relatif, hukuman tertinggi terdapat di Irak yakni 10 tahun dan minimal tiga tahun penjara dalam kasus perkawinan secara paksa. Sedangkan sanksi paling rendah adalah Mesir yakni satu bulan penjara dalam kasus petugas pencatat yang menolak atau tidak melaksanakan tugas pencatatan.

d. Alasan legal yang berlaku di Negara-negara Muslim dalam memberlakukan sanksi bagi pelaku talak di luar pengadilan adalah untuk mengurangi perceraian yang dibenci Allah dan memberikan hak terhadap perempuan secara wajar, atau lebih menekankan kepada pemberdayaan perempuan.

\section{PANDANGAN AKADEMISI HUKUM POSITIF TENTANG SANKSI TALAK DI LUAR PENGADILAN AGAMA}

Manusia sebagai makhluk sosial tidak akan pernah lepas dari kepentingan. Kepentingan itu adalah suatu tuntutan perorangan atau kelompok yang diharapkan untuk dipenuhi, manusia menginginkan agar kepentingannya terpenuhi sesuai dengan yang diharapkan. Untuk itu manusia memerlukan suatu peraturan yang mengatur setiap perilaku antara manusia yang satu dengan manusia yang lain untuk melindungi kepentingannya. Sebagaimana dalam masalah perkawinan, Pemerintah memberikan aturan-aturan untuk menertibkan dan mengatur tata cara perkawinan beserta akibatakibatnya sesuai dengan syari'at. Termasuk yang diatur Pemerintah adalah masalah talak. Talak telah diatur dalam Undang-undang Perkawinan No. 1 Tahun 1974 a pasal 39 "Perceraian hanya dapat dilakukan di depan sidang Pengadilan yang berwenang setelah Pengadilan yang bersangkutan tidak berhasil mendamaikan kedua belah pihak". Namun kenyataannya banyak masyarakat yang kebal hukum, artinya mereka lebih mempercayai pemuka Agama atau tokoh setempat dibandingkan dengan peraturan atau Undang-undang yang telah di sahkan dalam suatu Negara.

Sebagai bukti tindakan masyarakat tersebut, banyak masyarakat melakukan talak di luar Pengadilan Agama yang di latar belakangi berbagai macam alasan. Dalam 
hal ini para akademisi dalam bidang Hukum Positif memberikan beberapa keterangan. Dr. Saifullah, S.H., M.Hum menjelaskan:

Sebelum menjelaskan lebih lanjut mengenai sanksi di luar Pengadilan Agama, perlu mengetahui terlebih dahulu pengertian dan fungsi sanksi. Sanksi sebagaimana yang telah dijelaskan dalam beberapa literatur hukum, adalah sebuah alat pemaksa untuk mengindahkan norma-norma hukum. Selain sebagai alat untuk mengindahkan norma hukum, sanksi juga berfungsi sebagai alat penguat terhadap pelanggaran yang wujudnya dapat berupa sosial atau hukum.

Adapun dalam masalah talak, terdapat beberapa langkah untuk mewujudkannya, antara lain ${ }^{45}$ :

a. Melihat masalah sanksi talak di luar Pengadilan Agama bersifat sebagai penguat, maka secara formal harus disusun surat pernyataan tentang segala sesuatu kewajiban suami.

b. Melihat Indonesia sebagaia Negara hukum, maka proses penjatuhan sanksi yang sifatnya in formal (karena dilakukan di luar Pengadilan) lebih tepat berupa sanksi sosial.

c. Jika terdapat keinginan untuk merumuskan sanksi talak di luar Pengadilan Agama dalam regulasi Undang-undang, maka harus dilakukan upaya untuk memformulasikan sanksi dalam perundang-undangan. Kewajiban yang secara teknis dibuat oleh Mahkamah Agung, kemudian memerintahkan kepada Pengadilan Agama untuk menjatuhkan sanksi, meskipun proses tersebut tidak mudah dan jarang berhasil.

d. Pengadilan Agama dapat melakukan tindakan pengambil alihan wewenang terhadap pelaku talak untuk memberikan sanksi, bagi seseorang yang tidak melakukan talak karena belum memiliki akta.

Dalam masalah sanksi perdata yang akan dijatuhkan kepada pelaku talak di luar Pengadilan Agama, informan mencontohkan sebagaimana aturan yang telah berlaku dalam KUHP, yakni nilai rupiah sen X 17. Informan juga menjelaskan kendala-kendala bagi pelaku yang tidak memiliki akta, antara lain masalah ekonomi, geografis, sosial dan budaya.

\footnotetext{
${ }^{45}$ Wawancara dilakukan pada tanggal 28 Agustus 2013 jam 14.00 WIB di Kediaman Bapak Saifullah.
} 
Secara aplikatif informan masih meragukan pemberlakuan sanksi akan dijatuhkan kepada pihak laki-laki atau perempuan, karena keduanya sama-sama berstatus sebagai subyek hukum, selain itu informan mempertanyakan perlakuan hukum setelah pelaku melaksanakan sanksi yang dijatuhkan, apakah pelaku mengulangi ikrar talak kemudian diberi akta, atau pelaku di bebaskan dengan status hukum tetap, yakni tidak mendapat akta dan lain sebagainya.

Pembeian sanksi bagi pelaku talak di luar Pengadilan Agama juga di paparkan oleh Prof. Dr. Suhariningsih, SH.S.U, beliau menyatakan : ${ }^{46}$

Sanksi adalah sebuah hukuman yang diberlakukan terhadap seseorang yang terbukti melanggar aturan. Sanksi dapat diwujudkan apabila terdapat gugatan. Sedangkan dalam masalah talak yang termasuk dalam kategori hukum keluarga atau private sulit memberlakukan sanksi terhadap pelanggarnya, termasuk dalam hal ini pemberian sanksi bagi pelaku talak di luar Pengadilan Agama. Penjatuhan talak jelas diawali oleh sikap tidak baik atau melanggar, sehingga perlu pembuktian-pembuktian terhadap hal-hal yang dilanggar dalam perkawinan. Hal tersebut perlu dilakukan apabila seseorang ingin menjatuhkan sanksi, karena sanksi tidak dapat diberlakukan apabila tidak terdapat pihak yang melapor. Namun jika sanksi terhadap pelaku talak di luar Pengadilan Agama harus diwujudkan, maka sanksi yang tepat bagi pelaku talak di luar Pengadilan Agama adalah berupa sanksi yang berkaitan dengan pidana, pelaku dapat dikenai sanksi berupa sanksi sosial berupa teguran, atau pengasingan terhadap pelaku.

Selain keterangan di atas Dr. A. Rahmad Budiono, S.H. M.H. juga menjelaskan mengenai sanksi hukum talak di luar Pengadilan Agama. Beliau menjelaskan:

Lembaga-lembaga hukum di Indonesia yang diakui keabsahannya dan tidak bertentangan dengan hukum Negara harus disahkan, di dukung dan beri izin, seperti sekolahan dengan ijazah, Pengadilan Agama dengan surat putusan, dan pemilihan umum dengan menampung seluruh suara rakyat. ${ }^{47}$

\footnotetext{
${ }^{46}$ Wawancara dilakukan pada tanggal 9 Sepetember 2013 jam 10.00 WIB di ruang Dosen Hukum Perdata di Pascasarjan Fakultas Hukum Universitas Brawijaya Malang.

${ }^{47}$ Wawancara dilakukan pada tanggal 28 Agustus 2013 jam 10.00 WIB di Pascasarjan Fakultas Hukum Universitas Brawijaya Malang.
} 
Dalam hal ini informan membandingkan dengan masa Nabi. Pada masa Nabi sekolah adalah sarana belajar yang tidak memberlakukan ijazah, tujuan utama dari pembelajaran adalah menjadikan anak mengerti, namun di zaman sekarang sekolah selain untuk membuat anak didik mengerti juga memfasilitasi ijazah sebagai bukti bahwa anak didik tersebut pernah menjalani proses belajar-mengajar di sekolahan yang dimaksud. Begitu juga dengan putusan Pengadilan, jika zaman dahulu putusan Pengadilan tidak menyertakan surat putusan, maka saat ini sebagai legalitas dan bukti kongkrit keabsahan hukum yang berlaku bagi orang yang bersangkutan. Sama halnya dengan akta perceraian Negara harus mendukung keabsahan akta cerai sebagai bukti status hubungan pekawinan dan pengaruh akibat hukumnya. Al-Qur'an dan hadis tidak menjelaskan bahwa perceraian di luar Pengadilan Agama adalah melanggar hukum, namun al-Qur'an dan hadis menjelaskan norma-norma yang berlaku dalam agama Islam, seperti keadilan, perlindungan terhadap sesama, penghormatan dan kemaslahatan. Sebagaimana dalam hal ini al-Qur'an dan hadis secara ideal juga harus mendukung Negara sebagai sebuah komunitas yang membutuhkan nilai keadilan, begitu juga dalam masalah talak yang telah diatur dalam Undang-undang yang mengatakan bahwa talak harus di dalam Pengadilan Agama, maka jika talak dilakukan di luar Pengadilan Agama akibat hukumnya tidak boleh disamakan dengan talak yang dilakukan di dalam Pengadilan Agama.

Paparan di atas menurut informan adalah sebagai tindakan yang dilakukan agar terdapat perbedaan antara akibat hukum bagi pelaku talak di luar Pengadilan Agama dengan masyarakat yang melalui prosedur hukum dengan melakukan talak di dalam Pengadilan Agama. Informan lebih menyetujui penekanan akibat hukum bagi pelaku talak di luar Pengadilan Agama dari pada sanksi, karena pada prakteknya pemberian sanksi pada masyarakat sulit, hal ini di motifasi oleh kurangnya sosialisasi dari Pemerintah, faktor ekonomi serta budaya disekitarnya.

Berdasarkan wawancara dengan beberapa akademisi hukum positif, peneliti mendapatkan beberapan penjelasan tentang masalah talak di luar Pengadilan Agama. Akademisi hukum positif tidak setuju dengan pemberian sanksi di luar Pengadilan Agama, dengan alasan antara lain:

1) Sulitnya proses regulasi Undang-undang di Indonesia. 
2) Kurangnya sosialisasi Pemerintah tentang peraturan-peraturan dalam hal ini yang terkait masalah talak harus di depan sidang Pengadilan Agama.

3) Masyarakat kurang memiliki pengetahuan mengenai peraturan Pemerintah yang diberlakukan.

Berdasarkan alasan tersebut, maka akademsi hukum positif tidak melihat atas pemberian sanksi bagi pelaku talak di luar Pengadilan Agama, namun mereka lebih melihat kepada akibat hukum. Menurut akademisi hukum positif bukan sanksi yang harus diperjuangkan, namun akibat hukum bagi para pelaku pelanggar hukum dan norma hukum, sehingga bagi pelaku talak di luar Pengadilan Agama tidak bisa disamakan akibat hukumnya dengan pelaku talak di luar Pengadilan Agama.

Menurut akademisi hukum positif pemberian sanksi terhadap pelaku talak di luar Pengadilan Agama adalah sesuatu yang mustahil, karena sebuah sanksi hanya dapat diberikan terhadap seseorang yang terbukti melanggar, melihat pernyataan ini sanksi hanya dapat diwujudkan jika terdapat gugatan dari pihak lain yang merasa diperlakukan tidak semestinya.

Ketentuan mengenai talak atau perceraian yang terdapat dalam Undang-undang Nomor 1 Tahun 1974 pasal 39 ayat (1) perceraian hanya dapat dilakukan di depan sidang Pengadilan yang berwenang setelah Pengadilan yang bersangkutan tidak berhasil mendamaikan kedua belah pihak. Dalam aturan hukum Islam talak dianggap sebagai perbuatan yang sangat dibenci Allah, meskipun demikian talak tidak dapat dianggap sebagai sesuatu yang kultus dan tidak dapat terjadi, karena terkadang talak juga menjadi sebuah solusi untuk kebaikan rumah tangga. Dalam hukum Islam banyak ulama yang menggunakan hadis-hadis sebagai peringatan agar masyarakat tidak bermain-main dengan kata talak, seperti hadis:

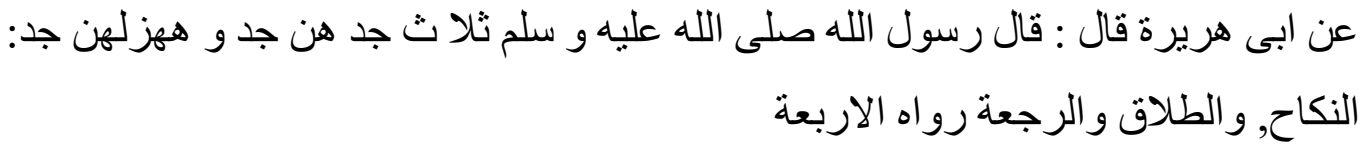

Artinya: "Hadis diriwayatkan oleh abu Hurairah, Rasulullah bersabda tiga hal yang keseriusannya menjadi nyata dan bercandanya menjadi nyata, yaitu : Nikah, talak dan ruju," (H.R. Imam empat).

Hadis di atas menunjukkan bahwa tiga hal termasuk talak adalah merupakan suatu perbuatan yang mengandung unsur peringatan hukum agar seorang suami berhati- 
hati dalam tutur katanya, selain itu hadis ini merupakan mengandung pesan moral yakni menjaga, menghormati dan bersikap adil terhadap pasangan dengan selalu berkata-kata lembut dan adil dalam memperlakukan istri dengan baik. ${ }^{48}$

Namun peneliti memandang lain, menurut peneliti hadis di atas tidak sesuai jika digunakan untuk mencari keadilan, karena hadis tersebut bertentangan dengan norma yang telah diajarkan al-Qur'an bahwa pernikahan harus dilakukan dengan serius tanpa bercanda atau bermain-main. Al-Qur'an telah menjelaskan secara tegas dalam surah alNisā' ayat 21:

Artinya: "Bagaimana kamu akan mengambilnya kembali padahal sebagian kamu telah bergaul (bercampur) dengan yang lain sebagai suami-isteri. Mereka (Istreiisteri) kamu telah mengambil dari kamu perjanjian yang kuat atau mitsāqan galizā."

Ayat di atas menunjukkan bahwa ikatan dalam perkawinan bukanlah ikatan yang dapat dipermainkan, namun ikatan dalam perkawinan bernilai serius. Bahkan seseorang melakukan pernikahan dapat dikatakan telah menyempurnakan sebagian ibadah, ibadah kepada Allah tidak mungkin dapat dilakukan dengan bercanda atau bermain. Implikasinya tidak dengan mudah seseorang mengucapkan talak kemudian jatuh talak dalam seketika, karena sebagaimana seseorang yang akan menikah diawali dengan niat baik, maka sama halnya dengan talak harus dilakukan dengan niat yang baik.

'Abduraḥmān bin Muhammad bin husain dalam karyanya Bughiyyah almustarsyidin menjelaskan bahwa talak yang dilakukan tanpa kehadiran dua orang saksi yang menyaksikan secara langsung berdasarkan pendengaran dan ucapannya, maka talak tersebut tidak sah. Padahal dalam Islam kebanyakan Ulama tidak mensyaratkan adanya saksi dalam perceraian, bahkan Peraturan Pemerintah yang diwujudkan dalam Kompilasi Hukum Islam tidak menyertakan perceraian harus disertai saksi. 'Abduraḥmān bin Muhammad bin ḥusain menyatakan :49

\footnotetext{
${ }^{48}$ Hadis tersebut diriwaytakan oleh Imam empat, dalam redaksi lain yang diriwatkan oleh Ibn 'Adi yakni menambah lafad al-Ṭalāqu wa al- 'itāqu wa al-Nikạhu bahwa tiga hal yang seriusnya berimplikasi pada hukum yang serius adalah talak, memerdekakan budak dan nikah. Namun meskipun begitu imam Hakim menilai hadis tersebut dengan predikat sahih. Lihat lebih lanjut Muhammad Ibn Ismā' ìl, Subul al-Salām Syarh bulūgh al-Marām min jam' adillah al-Ahkām, (Beirut: Lebanon, t.t)

49، Abdurahmān, Bughiyyah al-Mustarsyidin, (t.tp: Maktabah Dār al-Ih’”yā' al-'Arābiyyah, t.t), hlm. 223.
} 
لا يثبت الطلاق منجز ا أو مطلاقا الا بشهادة رجلين سمعا لفظه من الزوج أو وكيله و لا يقبل قول الوكيل على الزوج لو انكر الثـاهد أولم يجزم بشهادنـ. Artinya: Talaq tidak dapat ditetapkan (dianggap tetap) baik secara pasti, kecuali dengan penyaksian dua orang laki-laki baik persaksian secara pendengaran atau lafadz (ucapan) dari suami atau wakilnya, dan tidak diterima ucapan wakil dari suami dalam keadaan ingkar atau tidak menetapkan (ragu) atas persaksiannya.

Ungkapan di atas menunjukkan kewajiban mutlak bagi siapapun untuk menyertakan saksi dalam masalah perceraian, sehingga seseorang yang tidak dapat serta merta mencederai hukum Allah. Ungkapan di atas juga menjadi penjelas bahwa talak yang tidak disertai saksi hukumnya tidak sah. Hal ini sejalan dengan keberadaan sanksi dalam masalah talak di luar Pengadilan Agama yakni sebagai penguat aturan Undangundang . Adapun sanksi sebagai pencegah, bahwa keberadaan sanksi sebagai pencegah terjadinya talak terutama untuk talak di luar Pengadilan yang tidak disertai niat yang baik.

\section{PANDANGAN AKADEMISI HUKUM POSITIF DI KOTA MALANG TENTANG SANKSI TALAK DI LUAR PENGADILAN AGAMA.}

Menurut akademisi hukum positif, sanksi talak di luar Pengadilan Agama adalah sesuatu yang mustahil dan sulit diwujudkan, mereka kurang setuju dengan pemberian sanksi bagi pelaku talak di luar Pengadilan Agama, karena talak menurut mereka adalah tergolong wilayah hukum keluarga atau private sehingga tidak terdapat hak bagi siapapun untuk mencampuri terlebih menjatuhi sanksi.

Menurut peneliti pendapat tersebut meskipun secara trik benar, namun dalam penerapannya kurang bijak dan adil, karena mempertahankan masalah talak dalam kategori hukum private, sehingga tidak terdapat hak bagi siapapun untuk campur tangan di dalamnya, sama dengan membatasi hak asasi manusia terutama bagi perempuan, karena menurut akademisi hukum positif sanksi hanya dapat dilakukan jika terdapat laporan atau gugatan, dalam hal ini perempuan yang sadar atas kepentingan terhadap pembelaan harga diri dan kehormatannya harus memperjuangkan dan melapor kepada penegak hukum yakni Pengadilan Agama. Tindakan ini dilakukan untuk mewujudkan 
sanksi bagi pelaku talak di luar Pengadilan Agama yang kurang menghormati perempuan.

Akademsi hukum positif lebih menyetujui akibat hukum yang harus diberikan bagi pelaku talak di luar Pengadilan Agama bukan sanksi, menurut mereka pelaku talak di luar Pengadilan Agama tidak bisa disamakan akibat hukumnya dengan pelaku talak di luar Pengadilan Agama. Jika pelaku talak di Pengadilan Agama dapat melakukan akibat-akibat atas terjadinya perceraian, seperti pembagian harta dan penentuan hak asuh, maka bagi pelaku talak di luar Pengadilan Agama tidak dapat melakukan hal tersebut.

Menurut peneliti paparan di atas tidak mengandung unsur progres untuk perubahan sebuah nilai hukum, ungkapan di atas hanya berupa pilihan istilah agar sanksi tidak diberikan, karena sanksi sulit diwujudkan dan posisi talak berada pada wilayah hukum private. Menurut peneliti sanksi dibentuk tidak hanya untuk membuat seseorang jera atau enggan melakukan perbuatan yang dilarang, namun sanksi dibentuk sebagai alat pemaksa untuk mengindahkan sebuah norma hukum. Meskipun secara trik pemberian sanksi bagi pelaku talak di luar Pengadilan Agama sulit diwujudkan, karena talak termasuk hukum private, namun secara ajaran setiap hukum mengandung norma, baik norma keadilan, perlindungan terhadap sesama maupun menjaga kehormatan seseorang, hal ini sejalan dengan tujuan syariat dalam agama Islam, sebagaimana yang telah diyakini al-Gazāli:

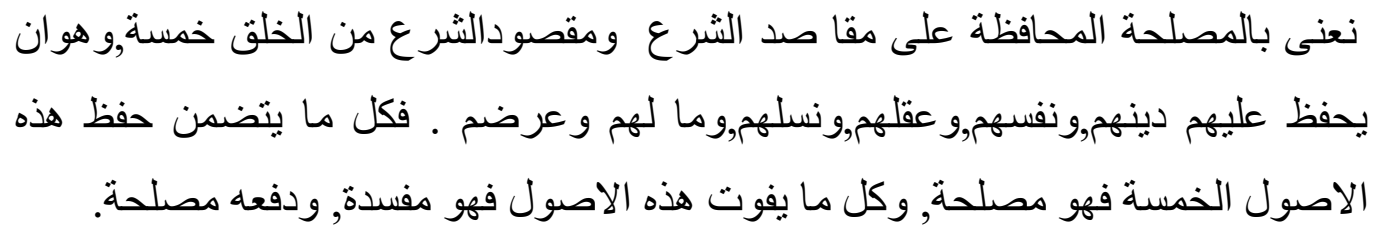

Artinya : "kami beranggapan terhadap maslahah, yaitu menjaga tujuan syari'at, dan tujuan syariat atas penciptaan makhluk yang lima, yaitu menjaga agama mereka, menjaga jiwa mereka, menjaga nasab mereka, dan kehormatan mereka. Setiap perkara yang mengandung penjagaan terhadap lima dasar tersebut, maka termasuk maslahah dan setiap sesuatu yang jauh dari lima dasar terebut bernilai mafsadah dan mencegah kemaslahatan."

Paparan di atas menyebutkan bahwa menjaga kehormatan termasuk usaha dari wujud penjagaan atas terciptanya kemaslahatan, sehingga peneliti lebih sepakat bahwa 
sanksi bagi pelaku talak di luar Pengadilan Agama harus diwujudkan, yang bertujuan untuk menjaga kehormatan perempuan dengan catatan setiap perempuan yang ditalak di luar Pengadilan Agama melapor kepada penegak hukum untuk diberi tindakan tegas berupa sanksi. Sanksi mampu menjadi instrument penting dalam mendukung dan menguatkan Undang-undang Nomor 1 tahun 1974 pasal 39 :

Selain alasan di atas, peneliti merujuk kepada beberapa Negara yang sudah memberlakukan ketentuan sanksi bagi pelaku talak di luar Pengadilan, meskipun sebagian kelompok konservatif masih beranggapan bahwa membawa masalah pribadi ke Pengadilan adalah sama saja dengan membawa aib di depan umum yang mengakibatkan demoralisasi kehidupan keluarga, namun pandangan tersebut ditolak oleh kalangan modernis, yang lebih memilih bahwa Pengadilan sebagai solusi yang berusaha menyeleseikan permasalahan dalam kehidupan pribadi.

Adapun mengenai jenis sanksi peneliti melihat terhadap jenis pelanggaran yang dilakukan oleh pelaku, dalam hal ini adalah talak di luar Pengadilan Agama. Menurut peneliti jika pelanggaran yang dilakukan adalah berkaitan dengan administrasi, maka jenis sanksi yang diberikan bersifat administratif, sebaliknya jika pelanggaran yang dilakukan berkaitan dengan norma maka jenis sanksi yang diberikan adalah sanksi definitif. Dalam tesis ini sanksi yang diberikan berupa sanksi administratif yaitu berupa sanksi denda, karena pelanggaran yang dilakukan berkaitan dengan administrasi yang telah diatur Pemerintah. Namun dalam menentukan biaya denda, pihak Pengadilan (hakim) menyesuaikan kemampuan pihak yang bercerai. Sanksi yang diberikan adalah denda uang, karena sanksi berupa denda uang akan memberikan peringatan dan mampu menimbulkan efek jera bagi pelaku talak di luar Pengadilan Agama, sehingga seseorang akan melakukan talak di Pengadilan, dan taat terhadap aturan Pemerintah.

\section{PANDANGAN AKADEMISI HUKUM ISLAM DI KOTA MALANG TENTANG SANKSI TALAK DI LUAR PENGADILAN AGAMA.}

Akademisi hukum Islam memliki pendapat lain dalam mememandang sanksi bagi pelaku talak di luar Pengadilan Agama, mereka setuju atas pemberian sanksi hukum, karena sanksi bagi pelaku talak di luar Pengadilan Agama mampu menjadi peringatan dan mampu memberikan efek jera bagi seseorang yang melakukan perceraian 
tanpa alasan hukum yang jelas, dan mencederai ikatan perkawinan yang merupakan ikatan kuat dan suci di mata Allah, sehingga seseorang dapat berfikir lebih serius sebelum melakukan tindakan yang dibenci oleh Allah.

Sejalan dengan pandangan akademisi hukum Islam, menurut peneliti dalam Undang-undang Nomor 1 Tahun 1974 tidak terdapat klausul yang menyatakan secara eksplisit bahwa perceraian yang dilakukan di luar Pengadilan sidang Pengadilan agama adalah tidak sah atau batal.

Kalimat "perceraian hanya dapat dilakukan di depan sidang Pengadilan" mampu menjadi media dalam menafsirkan bahwa perceraian yang dilakukan di luar sidang Pengadilan Agama tidak sah. Kalimat yang sama terdapat dalam Undang-undang Peradilan Agama Nomor 7 tahun 1989 yang menyatakan bahwa, "perceraian hanya dapat dilakukan di depan sidang Pengadilan yang berwenang setelah Pengadilan yang bersangkutan tidak berhasil mendamaikan kedua belah pihak ${ }^{\text {“ }}{ }^{50}$ Paparan tersebut juga menimbulkan penafsiran bahwa perceraian di luar sidang Pengadilan Agama tidak sah, karena tidak diawasi dan dicatat oleh Pengadilan.

Penafsiran ini sejalan dengan firman Allah :

Artinya: “Apabila mereka Telah mendekati akhir iddahnya, Maka rujukilah mereka dengan baik atau lepaskanlah mereka dengan baik dan persaksikanlah dengan dua orang saksi yang adil di antara kamu dan hendaklah kamu tegakkan kesaksian itu Karena Allah”.

Peneliti akan mempertegas dengan klausul dalam Kompilasi hukum Islam pasal 117 bahwa "talak adalah ikrar atau pernyataan cerai dari suami terhadap istri yang mengakibatkan putusnya perkawinan. Kemudian KHI pasal 118 " perceraian terjadi terhitung pada saat perceraian dinyatakan di depan sidang Pengadilan. Menurut peneliti ungkapan tersebut menunjukkan bahwa pernyataan cerai seorang suami kepada istrinya yang dilakukan di luar Sidang Pengadilan Agama dianggap bukan cerai, karena dilakukan di luar sidang Pengadilan Agama, tidak disertai saksi dan tidak dapat terhitung cerai karena tidak dalam pengawasan Pengadilan. Talak di luar pengadilan Agama juga berakibat ketidakabsahan pernikahan baru yang dilakukan antara suami dan istri berdampak besar terhadap status nasab keduanya karena istri masih berstatus memiliki

\footnotetext{
${ }^{50}$ Pasal 65 Undang-undang No. 7 tahun 1989 tentang Peradilan Agama.
} 
suami yang sah dimata hukum sedangkan suami tidak memiliki bukti kuat dimata hukum yaitu berupa bukti akte cerai sehingga suami tidak memiliki izin untuk menikah lagi.

Talak yang dilakukan di dalam sidang Pengadilan Agama dapat memberi perlindungan hukum terhadap mantan istri dan anak-anak mereka. Hak-hak mantan istri dan anak dapat terpenuhi karena mempunyai kekuatan hukum yang tetap. Sedangkan talak yang dilakukan di luar Pengadilan Agama tidak dapat memberi kepastian hukum terhadap mantan istri dan anak-anak mereka. Hak-hak mantan istri dan anak yang ditinggalkan pun tidak terjamin secara hukum. Hal ini juga menyebabkan mantan suami atau mantan istri tidak dapat menikah lagi dengan orang lain secara sah menurut hukum, oleh karena itu perlu adanya campur tangan Pemerintah yang sepenuhnya diberikan kepada Pengadilan Agama guna mencegah hal-hal yang tidak diinginkan.

Sebagai wujud dari sikap ingin menjaga agar talak tidak dilakukan di tempat yang tidak semestinya, akademisi hukum Islam menyetujui terhadap pemberian sanksi bagi pelaku talak di luar Pengadilan Agama, karena sanksi mampu menjadi wujud atas ajaran sahabat dalam menegakan hukum, yang bertujuan agar masyarakat tidak dengan mudah mempermainkan hukum. Sanksi bagi pelaku talak di luar Pengadilan Agama juga sebagai tindakan untuk menghindari penyalahgunaan hukum.

Menurut peneliti paparan tersebut sesuai dengan ajaran masa sahabat Umar Ibn Khattab kepada masyarakat Arab, masyarakat Arab yang gemar mengucapkan kata talāq diberikan sanksi hukum berupa terhitungnya talak tiga meksipun masih terucap satu kali. Tindakan tersebut tidak lain untuk mewujudkan kemaslahatan, karena jika dibiarkan talak di luar Pengadilan Agama akan semakin mengakar di masyarakat, dan tindakan tersebut dapat mencederai esensi perkawinan.

\section{KESIMPULAN}

Dari paparan di atas peneliti dapat menyimpulkan bahwa sanski dalam hukum Islam sebagai penguat, yaitu penguat terhadap aturan atau perintah Allah yang terdapat pada ayat 2 al-Quran surat at-Thalaq bahwa dalam talak harus menyertakan dua orang saksi yang adil, serta sebagai penguat terhadap Undang-undang yang menyebutkan bahwa talak harus dilakukan di depan sidang Pengadilan Agama. Selain sebagai penguat 
sanksi juga sebagai peringatan dan pencegah, terutama pencegahan terhadap talak yang dilakukan secara tidak baik dan tidak adil.

Menurut akademisi hukum positif bahwa pemberian sanksi hanya dapat dilakukan jika terdapat laporan atau gugatan dari salah satu pihak, dalam hal ini peneliti melihat perempuan memiliki kewajiban untuk melaporkan, untuk melindungi dirinya dan menghargai martabatnya, sehingga pelaku talak di luar Pengadilan Agama dapat diketahui dan diberikan sanksi. Adapun sanksi yang diberikan berupa sanksi administratif yaitu berupa sanksi denda, karena pelanggaran yang dilakukan berkaitan dengan administrasi yang telah diatur Pemerintah. Namun dalam menentukan biaya denda, pihak Pengadilan (hakim) yang menentukan nominal denda tersebut dengan melihat kemampuan pihak suami yang bercerai. Sanksi yang diberikan adalah denda uang, karena sanksi berupa denda uang akan memberikan peringatan dan mampu menimbulkan efek jera bagi pelaku talak di luar Pengadilan Agama, sehingga seseorang akan melakukan talak di Pengadilan, dan taat terhadap aturan Pemerintah.

\section{DAFTAR PUSTAKA}

'Abduraḥmān, Bughiyyah al-Mustarsyidin, t.tp: Maktabah Dār al-Ih”yā' al-'Arābiyyah, t.t.

Abdurahman Ghazali, Fiqih Munakahat, Jakarta: Prenata Media, 2002.

Abū Dāwud, Sunan Abū Dāwud, Beirut: Dār al-Kutub al -'Ilmiyah, 2003, II.

Abū Dāwud, Sunan Abū Dāwud, Beirut: Dār al-Kutub al -'Ilmiyah, 2003.

Ahmad Aulawi, Hukum Perkawinan Di Indonesia, Jakarta: Bulan bintang, 2004.

Amiur Nuruddin dan Azhari Akmal Taringan,, Hukum Perdata Islam Di Indonesia "Studi Kritis Perkembangan hukum Islam UU 1/1974 Sampai KHI, Jakarta: Kencana, 2006.

Ibn Ḥajar al-'Atsqālani, Bulūgh al-Marām, Surabaya: al-Hidayah, t.t.

Kamal Mukhtar, Asas-asas Hukum Perkawinan Islam Tentang Perkawinan, (Jakarta: Bulan Bintang, 1993.

Khoiruddin Nasution, Status Wanita di Asia Tenggara :Studi Terhadap Perundangundangan Perkawinan Muslim Kontenporer Indonesia Dan Malaysia, (Jakarta : INIS, 2002. 
Khoirudin Nasution, Hukum Keluarga di Dunia Islam Modern, Studi Perbandingan Dan Keberanjakan UU Modern Dari Kitab-Kitab Fikih, Jakarta: Ciputat Press, 2003.

Muhammad Ibn Ismā'ìl, Subul al-Salām Syarḥ bulūgh al-Marām min jam' adillah alAhkām, Beirut: Lebanon, t.t.

Muhammad Bin Qasim, Fathul Qarib Terjemah Ahmad Sunarto, Surabaya: al-Hidayah, 1992.

Muhammad Idris Ramulyo, Hukum Perkawinan Islam, Jakarta: Balai Pustaka, 2003.

Saifullah, Buku Ajar Konsep dasar Hukum Perdata Bagian 1, Malang: Fakultas Syar'ah UIN Malang, 2004.

Soemiyati, Hukum Perkawinan Islam Dan Undang-Undang Perkawinan 'UndangUndang No.1 Tahun 1974 Tentang Perkawinan', Yogyakarta: Liberti, 2004.

Syahar Saidus, Undang-undang Dan Masalah Pelaksanaanya (Ditinjau Dari Segi Hukum Islam), Bandung : Penerbit Alumni, 1981.

Tarmizi M. Jakfar, Poligami dan Talak Liar dalam Perspektif Hakim Agama di Indoneisa, Banda Aceh: ar-Raniry Press, 2007.

Yusuf Qaradhawi, Fiqih Wanita, Bandung: Jabal, 2009. 